medRxiv preprint doi: https://doi.org/10.1101/2021.01.29.21250771; this version posted February 1,2021 . The copyright holder for this preprint (which was not certified by peer review) is the author/funder, who has granted medRxiv a license to display the preprint in perpetuity.

It is made available under a CC-BY-NC-ND 4.0 International license .

HengSheng Fang ${ }^{1}$, Adam D. Wegman ${ }^{1}$, Kianna Ripich ${ }^{3}$, Heather Friberg ${ }^{2}$, Jeffrey R. Currier ${ }^{2}$, Stephen J. Thomas, Timothy P. Endy ${ }^{1}$, Adam T. Waickman ${ }^{1,3, *}$

\title{
Persistent COVID-19 symptoms minimally impact the development of SARS-CoV-2 specific cellular immunity
}

\author{
${ }^{1}$ Department of Microbiology and Immunology, State University of New York Upstate Medical \\ University, Syracuse, New York, USA \\ ${ }^{2}$ Viral Diseases Branch, Walter Reed Army Institute of Research, Silver Spring, MD, United States. \\ ${ }^{3}$ Institute for Global Health and Translational Sciences, State University of New York Upstate Medical \\ University, Syracuse, New York, USA.
}

*Corresponding author: waickmaa@upstate.edu

Key words: SARS-CoV-2, COVID-19, T cells, cellular immunity, symptom duration 
medRxiv preprint doi: https://doi.org/10.1101/2021.01.29.21250771; this version posted February 1, 2021. The copyright holder for this preprint (which was not certified by peer review) is the author/funder, who has granted medRxiv a license to display the preprint in perpetuity.

It is made available under a CC-BY-NC-ND 4.0 International license .

\section{ABSTRACT}

SARS-CoV-2 represents an unprecedented public health challenge with many unknowns remaining

51 regarding the factors that impact viral pathogenicity and the development of immunity after infection.

52 While the majority of SARS-CoV-2 infected individuals with mild-to-moderate COVID-19 resolve their

53 infection with few complications, a significant number of individuals experienced prolonged symptoms

54 lasting for weeks after initial diagnosis. Persistent viral infections are commonly accompanied by

55 immunologic dysregulation, especially within the cellular immune compartment. However, it is unclear if persistent mild-to-moderate COVID-19 impacts the development of virus-specific cellular immunity.

COVID-19 patients who experienced eight days or fewer of COVID-19 symptoms, or symptoms

61 immunity within both the CD4+ and CD8+ T cell compartments. Furthermore, we observed that

62 reactivity against the structural $\mathrm{N}$ protein from SARS-CoV-2 in convalescent COVID-19 patients

63 correlates with the amount of reactivity against the seasonal human coronaviruses 229E and NL63.

64 These results provide additional insight into the complex processes that regulate the development of

65 cellular immunity against SARS-CoV-2 and related human coronaviruses.

66 
medRxiv preprint doi: https://doi.org/10.1101/2021.01.29.21250771; this version posted February 1, 2021. The copyright holder for this preprint (which was not certified by peer review) is the author/funder, who has granted medRxiv a license to display the preprint in perpetuity.

It is made available under a CC-BY-NC-ND 4.0 International license .

\section{INTRODUCTION}

73 SARS-CoV-2 is a recently emerged novel single-stranded RNA virus that was initially identified as the

74 causative agent of a pneumonia outbreak in Wuhan, China in early December, 2019 [1-3]. This initial

75 outbreak has since developed into an unprecedented world-wide pandemic, resulting in an estimated 96

76 million infections and 2 million deaths as of January 2021. The multi-faceted illness associated with

77 SARS-CoV-2 infection - COVID-19 - is characterized by inflammation of the respiratory tract, fever,

78 musculoskeletal pain, and cough [4-6]. While SARS-CoV-2-specific humoral and cellular immunity is

79 evident in the majority of patients following the resolution of acute infection and appears to persist for at

80 least 6-8 months $[7,8]$, the role of this adaptive immune response in regulating viral replication and

81 disease pathogenesis remains unclear. Furthermore, little is known about how variations in the complex

82 clinical manifestations of COVID-19 impact the development of SARS-CoV-2 specific immunologic

83 memory.

A notable feature of SARS-CoV-2 infection is that COVID-19 symptoms can persist for weeks or

months after initial manifestation even in patients not requiring hospitalization or other medical

87 interventions $[9,10]$. This is especially evident in older adults with underlying chronic medical

conditions but has been extensively documented in patients across a wide age range [10]. Even in young adults, nearly $20 \%$ of patients with confirmed SARS-CoV-2 infection fail to return to full normal daily activities 14-21 days after the onset of COVID-19 symptoms and/or a positive SARS-CoV-2 test in an

91 outpatient setting [11]. Although replication-competent SARS-CoV-2 has been difficult to detect in

92 individuals with protracted COVID-19 symptoms, recovered patients continue to shed detectable SARS-

93 CoV-2 RNA in their upper respiratory tract and in their stool for weeks after initial diagnosis [12-14]. 
medRxiv preprint doi: https://doi.org/10.1101/2021.01.29.21250771; this version posted February 1, 2021. The copyright holder for this preprint (which was not certified by peer review) is the author/funder, who has granted medRxiv a license to display the preprint in perpetuity.

It is made available under a CC-BY-NC-ND 4.0 International license .

94 Furthermore, indirect immunologic evidence of SARS-CoV-2 antigen persistence has been observed,

95 most notably reflected in the maturation profile of SARS-CoV-2 specific memory B cells [15].

97 The presence of persistent viral antigen and/or infection-attendant inflammation is associated with

98 immune dysregulation in many viral infections [16]. This is most prominently manifested within the

99 cellular immune compartment where persistent antigen stimulation and/or inflammatory cytokine

100 exposure can lead to a progressive loss of $\mathrm{T}$ cell effector function and suppression of pathogen-specific

101 cellular immunity $[17,18]$. While this phenomenon has been well documented in chronic viral diseases

102 such as HBV/HCV and HIV [18], it is currently unclear if the persistence of mild-to-moderate COVID-

10319 symptoms is associated with the development of a dysfunctional or sub-optimal cellular immune

104 response.

To fill this knowledge gap, we examined the relationship between the duration of COVID-19 symptoms

107 and the magnitude and functional profile of SARS-CoV-2 specific cellular immunity in individuals

108 recently recovered from mild-to-moderate COVID-19. Using an IFN- $\gamma$ ELISPOT assay, we observed

109 that patients with protracted COVID-19 symptoms exhibited similar levels of SARS-CoV-2 specific

110 cellular immunity overall as individuals who rapidly resolved their symptoms; although prolonged

111 COVID-19 symptoms were associated with slightly elevated responses against SARS-CoV-2 ORF3a

112 and ORF7a. Furthermore, no defect was observed in the magnitude of the SARS-CoV-2 Spike specific

113 CD4+ and CD8+ T cell response in individuals with prolonged COVID-19 symptoms when assessed

114 using flow cytometry, and the transcriptional profile of SARS-CoV-2 specific CD4 T cells was observed

115 not to be impacted by the duration of COVID-19 symptoms. Finally, while significant levels of cellular

116 immunity against the seasonal human coronaviruses 229E and NL63 were observed in all convalescent 
117 COVID-19 patients analyzed in the study, the magnitude of this immune response did not correlate with

118 the duration of COVID-19 symptoms. However, a significant negative correlation was observed

119 between patient age and the overall magnitude of 229E/NL63 reactivity across all donors, and the level

120 of 229E and NL63 Spike reactivity did correlate with reactivity against the structural N protein from

121 SARS-CoV-2. These data suggest that prolonged symptomatic COVID-19 does not significantly impact

122 the development of SARS-CoV-2 specific cellular immunity or cellular immunity against related

123 seasonal human coronaviruses in patients with mild/moderate disease, but that prior infection with

124 seasonal human betacoronaviruses may selectively influence the development of N specific SARS-CoV-

1252 cellular immunity.

126

127

128

129

130

131

132

133 
medRxiv preprint doi: https://doi.org/10.1101/2021.01.29.21250771; this version posted February 1, 2021. The copyright holder for this preprint (which was not certified by peer review) is the author/funder, who has granted medRxiv a license to display the preprint in perpetuity.

It is made available under a CC-BY-NC-ND 4.0 International license.

\section{RESULTS}

Convalescent COVID-19 patient selection and characterization. The objective of this study was to determine the impact of COVID-19 symptom duration on the magnitude and functional profile of SARS-CoV-2 specific cellular immunity. To this end, subjects were identified within the SUNY Upstate Convalescent COVID-19 Plasma Donor protocol who experienced a PCR confirmed SARS-CoV-2 infection and from whom PBMC were obtained 14 to 30 days following the resolution of COVID-19 associated symptoms (Figure 1A). A total of 84 subjects were identified within the parental protocol who fulfilled these selection criteria, of which 33 were selected for further analysis (Table 1). Within this group of 33 donors, 14 subjects were classified as having a "short" period of COVID-19 associated symptoms (0-8 days), while 19 subjects were classified as having a "long" duration of COVID-19 associated symptoms (18-61 days). No correlation was observed between subject age and the duration of self-reported COVID-19 symptoms (Figure 1B), and all subjects were otherwise healthy at the time of PBMC collection.

\section{Assessment of SARS-CoV-2 specific cellular immunity stratified by COVID-19 symptom duration.}

To determine if the magnitude and antigen-specificity of SARS-CoV-2 elicited cellular immunity is impacted by the duration of COVID-19 symptoms, PBMC from the 33 subjects selected above were analyzed using an IFN- $\gamma$ ELISPOT assay. Overlapping peptide pools spanning the Spike, N, M, ORF3a, and ORF7a proteins from SARS-CoV-2 were used in this analysis (Supplemental Table 1). SARS-

CoV-2 specific cellular immunity - defined as a subject having more than 50 IFN- $\gamma$ producing SARSCoV-2 specific cells per $10^{6}$ PBMC - was observed in $85.7 \%(13 / 14)$ of subjects classified as having a

61 short duration of COVID-19 symptoms, while 94.7\% (18/19) of subjects with a long duration of

62 COVID-19 symptoms exhibited a positive response (Table 1). However, no difference in the total 
medRxiv preprint doi: https://doi.org/10.1101/2021.01.29.21250771; this version posted February 1, 2021. The copyright holder for this preprint (which was not certified by peer review) is the author/funder, who has granted medRxiv a license to display the preprint in perpetuity.

It is made available under a CC-BY-NC-ND 4.0 International license .

163 SARS-CoV-2 specific cellular immune response was observed between these two groups when stratified 164 by the duration of self-reported COVID-19 symptoms (Figure 2A, Supplemental Figure 1). When

165 further stratified by viral antigen, no difference in the level of reactivity against SARS-CoV-2 Spike, N, 166 and $\mathrm{M}$ was observed between individuals with either a short or long duration of COVID-19 symptoms

167 (Figure 2B). A statistically significant higher level of ORF3a and OFR7a reactivity was observed in 168 individuals with longer periods of COVID-19 symptoms than in individuals with a short period of 169 COVID-19 associated symptoms (Figure 2B), but most of these responses fell under the 50 SFC/10 170 PBMC threshold for positivity (Table 1).

172 To further define the profile of SARS-CoV-2 specific cellular immunity and how it stratifies by

173 COVID-19 symptom duration, we assessed the multi-parametric antigen reactivity pattern captured in 174 our ELISPOT analysis. Most individuals included in this analysis exhibited cellular immunity against 175 two-or-more SARS-CoV-2 antigens, with 71.3\% of individuals with a short period of COVID-19 symptoms and $68.4 \%$ of individuals that experienced a long period of COVID symptoms exhibiting a 177 multivalent antigen response (Figure 2C). The most common multi-antigen reactivity pattern observed 178 in individuals with a short duration of COVID-19 symptoms was a trivalent response against SARS179 CoV-2 Spike, N, and M proteins (Figure 3C). In contrast, the most common antigen reactivity pattern 180 observed in individuals with a long duration of COVID-19 symptoms was a tetravalent response against 181 SARS-CoV-2 Spike, N, M and ORF3a.

183 Flow cytometric assessment of SARS-CoV-2 antigen reactivity. To further define the cellular 184 disposition of the SARS-CoV-2 specific cellular immune response quantified in our ELISPOT analysis, 185 a second aliquot of PBMC from 10 convalescent COVID-19 patients (5 with short symptoms, 5 with 
medRxiv preprint doi: https://doi.org/10.1101/2021.01.29.21250771; this version posted February 1, 2021. The copyright holder for this preprint (which was not certified by peer review) is the author/funder, who has granted medRxiv a license to display the preprint in perpetuity.

It is made available under a CC-BY-NC-ND 4.0 International license .

186 prolonged symptoms) that were determined to have high levels of SARS-CoV-2 specific cellular

187 immunity were stimulated with a SARS-CoV-2 Spike protein peptide pool and the level of SARS-CoV-

1882 specific cellular immunity quantified by flow cytometry. SARS-CoV-2 reactive CD8+ and CD4+ T

189 cells were identified by their respective upregulation of CD25/CD69 or CD134/CD69 following peptide

190 stimulation. A robust population of SARS-CoV-2 reactive CD8+ T cells were identified in the subjects

191 selected for analysis (Figure 3A, Supplemental Figure 2), although the abundance of these cells did

192 not significantly differ when stratified by the duration of COVID-19 symptoms (Figure 3B). The

193 magnitude of SARS-CoV-2 Spike protein specific cellular immunity measured by IFN- $\gamma$ ELISPOT

194 correlated well with the CD8+ T cell SARS-CoV-2 specific cellular immunity as quantified by flow

195 cytometry (Figure 3C). In addition to this SARS-Cov-2 Spike protein specific CD8+ T cell response, a 196 quantifiably more robust CD4+ T cell response was observed in all donors (Figure 3A, Supplemental

197 Figure 2), with most subjects exhibiting a $\sim 50 \%$ higher frequency of SARS-CoV-2 Spike reactive CD4

198 T cells than CD8 T cells (Supplemental Figure 3). Again, the overall magnitude of the SARS-CoV-2

199 specific CD4+ T cell response was not impacted by the duration of COVID-19 symptoms. However,

200 there was a very poor correlation between SARS-CoV-2 Spike protein specific CD4+ T cell response as

201 quantified by flow cytometry and the SARs-CoV-2 Spike reactivity as quantified by IFN- $\gamma$ ELISPOT,

202 highlighting the differential utility of the two assays.

203

204 Transcriptional characterization of SARS-CoV-2 reactive CD4+ T cells. Persistent antigen

205 simulation is known to result in transcriptional- and functional-dysregulation of pathogen-specific T

206 cells and loss of effector function [19]. While no significant difference in the abundance of SARS-CoV-

2072 reactive CD4 and CD8 T cells were noted in the convalescent COVID-19 patients included in this

208 study when stratified by symptom duration, we wished to confirm that the functional transcriptional 
medRxiv preprint doi: https://doi.org/10.1101/2021.01.29.21250771; this version posted February 1, 2021. The copyright holder for this preprint (which was not certified by peer review) is the author/funder, who has granted medRxiv a license to display the preprint in perpetuity.

It is made available under a CC-BY-NC-ND 4.0 International license .

209 profile of SARS-CoV-2 reactive CD4+ T cells was not negatively impaired in individuals experiencing

210 prolonged COVID-19 symptoms. Therefore, we sorted SARS-CoV-2 Spike protein reactive CD4 T cells

211 from the 10 donors highlighted above and subjected them to transcriptional profiling. An average of

212 2,322 SARS-CoV-2 reactive CD4+ T cells were isolated from each donor (range 106 - 4,497) and were

213 subjected to mRNA sequencing analysis.

215 As expected, the cells recovered in this analysis expressed high levels of canonical CD4+ T cell gene 216 products (CD3E, CD4, CD40LG) along with the activation markers used to identify/isolate the cell in 217 the flow cytometry assay (Figure 4A). The sorted SARS-CoV-2 specific CD4+ T cells expressed high

218 levels of canonical Th1-assocaited gene products (IFNG, TNF, TBX21), but appreciably lower levels of 219 Th2/Th17 associated transcripts (Figure 4B). However, no differentially expressed genes were 220 identified between the samples when segregated by symptom duration, and no appreciable difference 221 was observed in the global transcriptional profile between the two groups (Figure 4B). These results 222 suggest that the duration of COVID-19 symptoms minimally impacts the resultant transcriptional profile 223 of SARS-CoV-2 reactive CD4+ T cells in patients recently recovered from mild/moderate COVID-19.

Persistent COVID-19 symptoms do not correlate with seasonal coronavirus reactivity. Cellular

226 immunity against SARS-CoV-2 antigens has been observed in PBMC samples collected prior to the 227 emergence of the virus in December 2019 [19-21]. This has been primarily attributed to cross-reactive 228 cellular immunity elicited by seasonal human coronaviruses such as 229E and NL63 which widely 229 circulate and share some degree of antigen similarity with SARS-CoV-2 [19]. While the impact of pre230 existing/cross-reactive cellular immunity on the clinical progression of SARS-CoV-2 infection remains 231 unclear, we endeavored to determine if the presence of seasonal human coronavirus specific cellular 
medRxiv preprint doi: https://doi.org/10.1101/2021.01.29.21250771; this version posted February 1, 2021. The copyright holder for this preprint (which was not certified by peer review) is the author/funder, who has granted medRxiv a license to display the preprint in perpetuity.

It is made available under a CC-BY-NC-ND 4.0 International license .

232 immunity in convalescent COVID-19 patients correlated with the duration of self-reported symptoms, 233 and if the magnitude of seasonal human coronavirus cellular immunity correlated with SARS-CoV-2 234 specific cellular immunity.

236 To this end, we utilized overlapping peptide pools spanning the Spike proteins of the human seasonal 237 coronaviruses 229E and NL63 to stimulate PBMC from the same donors described above in a parallel 238 IFN- $\gamma$ ELISPOT assay. While the majority of subjects exhibited reactivity against the Spike protein from 239 both 229E and NL63, persistent COVID-19 symptoms did not statistically impact magnitude of 229E 240 (Figure 5A) or NL63 (Figure 5B) Spike protein reactivity as assessed by IFN- $\gamma$ ELISPOT. While the 241 magnitude of 229E and NL63 reactivity within a given subject correlated with each other, the magnitude 242 of SARS-CoV-2 Spike protein reactivity observed in a given subject does not correlate with their 243 reactivity to Spike from 229E or NL63 (Figure 5C), suggesting that these cellular populations may be 244 distinct in convalescent COVID-19 patients. Interestingly, despite the lack of correlation between 245 NL63/229E Spike reactivity and SARS-CoV-2 Spike reactivity, the presence of either NL63 or 229E 246 Spike reactivity did correlate with reactivity against the SARS-CoV-2 N protein (Figure 5C). Finally, 247 while we noted no significant association between the magnitude of SARS-CoV-2 specific cellular 248 immunity and donor age in our study (Supplemental Figure 4), a significant negative correlation was 249 observed between the total magnitude of 229E and NL63 reactivity and subject age in our dataset 250 (Figure 5D). 
medRxiv preprint doi: https://doi.org/10.1101/2021.01.29.21250771; this version posted February 1, 2021. The copyright holder for this preprint (which was not certified by peer review) is the author/funder, who has granted medRxiv a license to display the preprint in perpetuity.

It is made available under a CC-BY-NC-ND 4.0 International license.

\section{DISCUSSION}

256 In this study, we examined the relationship between the duration COVID-19 symptoms and the

257 magnitude and functional profile of SARS-CoV-2 specific cellular immunity in individuals recently

258 recovered from mild/moderate COVID-19. We observed that patients with prolonged COVID-19

259 symptoms overall exhibited similar levels of SARS-CoV-2 specific cellular immunity as individuals

260 who rapidly resolved their symptoms. No defect was observed in the magnitude of the SARS-CoV-2

261 Spike specific CD4 and CD8 T cell response in individuals with prolonged COVID-19 symptoms when

262 assessed using flow cytometry, and the transcription profile of SARS-CoV-2 specific CD4 T cells was

263 observed not to be influenced by the duration of COVID-19 symptoms. Finally, while significant levels

264 of cellular immunity against the seasonal human coronaviruses 229E and NL63 was observed in all

265 convalescent COVID-19 patients analyzed in the study, the magnitude of this immune response did not

266 correlate with the duration of COVID-19 symptoms. These data suggest that prolonged symptomatic

267 COVID-19 does not significantly impact the development of SARS-CoV-2 specific cellular immunity in 268 patients with mild/moderate disease.

270 The development of SARS-CoV-2 specific cellular immunity has been ubiquitously observed following

271 the resolution of COVID-19 symptoms and may be a more sensitive immunologic indication of SARS-

272 CoV-2 infection than conventional seroconversion [22, 23]. Indeed, higher levels of both cellular and

273 humoral immunity have been observed in patients after the resolution of severe COVID-19 than

274 following mild or asymptomatic infections [24]. However, the quality of the cellular immune response

275 generated after severe COVID-19 is of uncertain quality, as severe COVID-19 is associated with severe

276 T cell dysregulation, exhaustion, and inflammatory cytokine production [25, 26]. As we did not observe

277 any appreciable deficit in either the quantity or the quality of the SARS-CoV-2 specific cellular immune 
medRxiv preprint doi: https://doi.org/10.1101/2021.01.29.21250771; this version posted February 1, 2021. The copyright holder for this preprint (which was not certified by peer review) is the author/funder, who has granted medRxiv a license to display the preprint in perpetuity.

It is made available under a CC-BY-NC-ND 4.0 International license .

278 profile in the individuals analyzed in our study, we feel that it is reasonable to hypothesize that the

279 immunologic mechanisms underpinning severe COVID and persistent mild COVID-19 are distinct and

280 may differentially impact the development of virus-specific cellular memory.

282 While it was not unexpected to observe cellular reactivity against coronaviruses other than SARS-CoV-

2832 in the convalescent COVID-19 patients analyzed in our study, the lack of correlation between the

284 magnitude of SARS-CoV-2 Spike protein reactivity and reactivity against Spike from the seasonal

285 coronaviruses 229E and NL63 was unexpected. Preexisting cellular immunity against common seasonal

286 human coronaviruses - such as 229E, NL63, OC43, and HKU1- has been highlighted as the most likely

287 explanation for the relativity high frequency of individuals with SARS-CoV-2 specific cellular

288 immunity prior to the appearance of the virus [19-21]. Additionally, it is notable that the level of 229E

289 and NL63 Spike reactivity did correlate with the amount of SARS-CoV-2 N reactivity in convalescent

290 COVID-19 patients analyzed in our study. This result is consistent with other previously published

291 reports that suggest that coronavirus infections - including infection with seasonal betacoronaviruses

292 and SARS-CoV - may preferentially result in durable cellular memory against the structural N protein

293 that cross-reacts with SARS-CoV-2 [21]. In addition to providing insight into the mechanisms driving

294 the development of SARS-CoV-2 specific cellular immunity, this observation may provide guidance as

295 to which antigens may be most amenable in the development of a universal coronavirus vaccine. 
medRxiv preprint doi: https://doi.org/10.1101/2021.01.29.21250771; this version posted February 1, 2021. The copyright holder for this preprint (which was not certified by peer review) is the author/funder, who has granted medRxiv a license to display the preprint in perpetuity.

It is made available under a CC-BY-NC-ND 4.0 International license .

\section{METHODS}

302 Study design: Convalescent COVID-19 patients were recruited for this study at the SUNY Upstate

303 Medical University Clinical Research Unit starting in March 2020 under the SUNY Upstate

304 Convalescent Plasma Donor Program [27]. This study was reviewed by the SUNY Upstate Medical

305 University IRB, reviewed approved by the Western Institutional Review Board (IRB \# 1587400), and

306 performed under informed consent. All subjects were adults 18 year of age or older who had previously

307 tested positive for SARS-CoV-2 and who were symptom-free for at least 14 days prior to enrollment.

308 Information regarding the timing and duration of acute COVID-19 symptoms - such as fever, shortness

309 of breath, sore throat, cough that impacted activity, and fatigue that impacted activity -were self-

310 reported. Lingering symptoms such as loss of taste and smell, mild cough or tickle in the throat, or

311 lingering fatigue that did not impact their daily activity were not considered part of the acute illness and

312 therefore not included in the length of illness. For asymptomatic donors identified via contract tracing

313 protocols the date of positive RT-PCR test was used for the start and stop date of symptoms. Samples

314 were de-identified following collection, and researchers conducting assays were blinded to clinical data

315 until final comparative analysis. PBMC were collected and processed using Vacutainer CPT Cell

316 Preparation Tubes (BD) and stored in vapor phase liquid nitrogen prior to analysis.

318 IFN- $\boldsymbol{\gamma}$ ELISPOT: Cryopreserved PBMC were thawed, washed twice, and placed in RPMI 1640

319 medium (Corning, 10040CM) supplemented with 10\% heat-inactivated Fetal Calf Serum (Corning, 35-

320 010-CV), L-glutamine (Lonza, 17-605E), and Penicillin/Streptomycin (Gibco, 15140-122). Cellular

321 viability was assessed by trypan blue exclusion and cells were resuspended at a concentration of

$3225 \times 10^{6} / \mathrm{ml}$ and rested overnight at $37^{\circ} \mathrm{C}$. After resting, viable PBMC were washed, counted, and

323 resuspended at a concentration of $1 \times 10^{6} / \mathrm{ml}$ in complete cell culture media. $100 \mu$ l of this cell suspension 
medRxiv preprint doi: https://doi.org/10.1101/2021.01.29.21250771; this version posted February 1, 2021. The copyright holder for this preprint (which was not certified by peer review) is the author/funder, who has granted medRxiv a license to display the preprint in perpetuity.

It is made available under a CC-BY-NC-ND 4.0 International license .

was mixed with $100 \mu$ of the individuals peptide pools listed in Supplemental Table 2 and diluted to a final concentration $1 \mu \mathrm{g} / \mathrm{mL} /$ peptide (DMSO concentration $0.5 \%$ ) in complete cell culture media. This cell and peptide mixture was loaded onto a 96-well PVDF plate coated with anti-IFN- $\gamma(3420-2 \mathrm{HW}-$ Plus, Mabtech) and cultured overnight. Controls for each donor included 0.5\% DMSO alone (negative) and anti-CD3 (positive). After overnight incubation the ELISPOT plates were washed and stained with anti-IFN- $\gamma$-biotin followed by streptavidin-conjugated HRP (3420-2HW-Plus, Mabtech). Plates were developed using TMB substrate and read using a CTL-ImmunoSpot@ S6 Analyzer (Cellular Technology Limited). All peptide pools were tested in duplicate and the adjusted mean was reported as the mean of the duplicate experimental wells after subtracting the mean value of the negative (DMSO only) control wells. Individuals were considered reactive to a peptide pool when the backgroundsubtracted response was $>50$ Spot Forming Cells (SFC)/10 6 PBMC. All data were normalized based on the number of cells plated per well and are presented herein as SFC/10 ${ }^{6} \mathrm{PBMC}$.

Flow Cytometry: Surface staining for flow cytometry analysis was performed at room temperature in PBS supplemented with 2\% FBS. Aqua Live/Dead (ThermoFisher, L34957) was used to exclude dead cells in all experiments. Antibodies and dilutions used for flow cytometry analysis are listed in Supplementary Table 2. Flow cytometry analysis was performed on a BD FACSAria II instrument and analyzed using FlowJo v10.7 software (Treestar).

Isolation and transcriptional analysis of SARS-CoV-2 reactive $\mathrm{CD4}^{+}$T cells: Cryopreserved $\mathrm{PBMC}$ samples were thawed and resuspended in complete cell culture media at a concentration of $5 \square \times \square 10^{6}$ cells/mL and stimulated with $0.5 \square \mu \mathrm{g} / \mathrm{mL}$ of a SARS-CoV-2 Spike protein peptide pool (Supplementary Table 2) for $18 \square$ hours at $37 \square^{\circ} \mathrm{C}$. Spike-reactive $\mathrm{CD}^{+} \mathrm{T}$ cells were identified by expression of the 
medRxiv preprint doi: https://doi.org/10.1101/2021.01.29.21250771; this version posted February 1, 2021. The copyright holder for this preprint (which was not certified by peer review) is the author/funder, who has granted medRxiv a license to display the preprint in perpetuity.

It is made available under a CC-BY-NC-ND 4.0 International license .

347 activation markers CD134 and CD69 and isolated by flow cytometric sorting using BD FACSAria II

348 instrument. Cells were sorted directly into $350 \mu 1$ RLT+ buffer (Qiagen, 1053393) supplemented with

349 1\% 2-ME and RNA isolated using a RNeasy Micro spin column (Qiagen, 74004). cDNA was generated

350 using a SMART-Seq HT Kit (TaKaRa, 634455), and the final Illumina-compatible DNA sequencing

351 libraries were prepared using an Illumina Nextera XT DNA Library Preparation kit. RNA, cDNA, and

352 DNA during the library preparation process were quantified using Agilent Bioanalyzer, and final

353 libraries were sequenced using a 75 cycle High Output NextSeq 500/550 v2.5 reagent kit at the SUNY

354 Upstate Molecular Analysis Core. Raw reads from FASTQ files were mapped to the human reference

355 transcriptome (Ensembl, Home sapiens, GRCh38) using Kallisto [28] version 0.46.2. Transcript-level

356 counts and abundance data were imported and summarized in R (version 4.0.2) using the TxImport

357 package [29] and TMM normalized using the package EdgeR [30, 31]. Differential gene expression

358 analysis performed using linear modeling and Bayesian statistics in the R package Limma [32].

Statistical analysis: Statistical analyses were performed using GraphPad Prism v8 Software (GraphPad

361 Software, La Jolla, CA). A $p$-value $<0.05$ was considered significant. 
medRxiv preprint doi: https://doi.org/10.1101/2021.01.29.21250771; this version posted February 1, 2021. The copyright holder for this preprint (which was not certified by peer review) is the author/funder, who has granted medRxiv a license to display the preprint in perpetuity.

It is made available under a CC-BY-NC-ND 4.0 International license .

\section{AUTHOR CONTRIBUTIONS}

371 HSF: Investigation, ADW: Investigation, KR: Investigation, Project administration, HF: Methodology,

372 JRC: Methodology, SJT: Conceptualization, Project administration, Supervision, Methodology, TPE:

373 Conceptualization, Project administration, Supervision, Methodology, ATW: Conceptualization, Data

374 curation, Formal analysis, Funding acquisition, Investigation, Methodology, Visualization, Writing -

375 original draft, Writing - review \& editing

376

377

378

379

380

381

382

383

384

385

386

387

388

389

390

391

392

393 
medRxiv preprint doi: https://doi.org/10.1101/2021.01.29.21250771; this version posted February 1, 2021. The copyright holder for this preprint (which was not certified by peer review) is the author/funder, who has granted medRxiv a license to display the preprint in perpetuity.

It is made available under a CC-BY-NC-ND 4.0 International license .

\section{ACKNOWLEDGEMENTS}

395 We wish to thank all the study participants for making this work possible, Mark Abbott and Kristen

396 Baxter for critical laboratory support, Lisa Phelps for support with the SUNY Upstate Medical

397 University flow cytometry core, Karen Gentile for support with the SUNY Upstate Molecular Analysis

398 Core, and Kristen Newell and Joel Wilmore for helpful discussion. This work was internally funded by

399 the State University of New York. Material has been reviewed by the Walter Reed Army Institute of

400 Research. There is no objection to its presentation and/or publication. The opinions or assertions

401 contained herein are the private views of the author, and are not to be construed as official, or as

402 reflecting true views of the Department of the Army or the Department of Defense. The investigators

403 have adhered to the policies for protection of human subjects as prescribed in AR 70-25

\section{Competing Interests}

406 SJT reports other from Pfizer, during the conduct of the study; personal fees from Merck, personal fees 407 from Sanofi, personal fees from Takeda, personal fees from Themisbio, personal fees from Janssen, 408 outside the submitted work. All other authors declare that the research was conducted in the absence of 409 any commercial or financial relationships that could be construed as a potential conflict of interest.

\section{Data availability}

412 The authors declare that all data supporting the findings of this study are available within this article or

413 from the corresponding author upon reasonable request. RNAseq gene expression data have been

414 deposited in the Gene Expression Omnibus database (GSE165373). 
medRxiv preprint doi: https://doi.org/10.1101/2021.01.29.21250771; this version posted February 1, 2021. The copyright holder for this preprint (which was not certified by peer review) is the author/funder, who has granted medRxiv a license to display the preprint in perpetuity. It is made available under a CC-BY-NC-ND 4.0 International license .

\section{FIGURE LEGENDS}

Figure 1. Study design and patient characteristics. A) Schematic representation of the subject selection criteria used in this study and the timing of sample collection. B) Analysis of the relationship between subject age and the duration of self-reported COVID-19 symptoms in all subjects included in this analysis. Filled circles indicate subjects included in the "short" duration of symptoms group. Empty circles indicate individuals included in the "long" duration of symptoms group. $\mathrm{r}^{2}$ and $\mathrm{p}$ value calculated by 2-tailed Pearson Correlation test.

Figure 2. Assessment of SARS-CoV-2 specific cellular immunity by IFN- $\gamma$ ELISPOT. A) Total magnitude of SARS-CoV-2 specific cellular immunity in all study participants as defined by total reactivity against SARS-CoV-2 Spike, N, M, ORF3a and ORF7a antigens. Subjects split by duration of self-reported symptoms. Dashed line indicates a $50 \mathrm{SFC} / 10^{6} \mathrm{PBMC}$ threshold for a positive response. B) Magnitude of SARS-CoV-2 specific cellular immunity separated by major antigen in all study participants. Dashed line indicates a $50 \mathrm{SFC} / 10^{6} \mathrm{PBMC}$ threshold for a positive response. C) Pattern of multi-antigen SARS-CoV-2 reactivity in all study subjects split by duration of self-reported symptoms. Arc color and arc length indicates reactivity against a given SARS-CoV-2 antigen. Internal plot wedge size indicates fraction of individuals with the indicated pattern of antigen reactivity. $* * * p<0.001$, ** $\mathrm{p}$ $<0.01$ unpaired 2-tailed $\mathrm{T}$ test

Figure 3. Flow cytometric quantification of SARS-CoV-2 Spike protein specific cellular immunity A) Representative flow cytometry plot demonstrating CD25 and CD69 upregulation in CD8+ T cells following in vitro SARS-CoV-2 Spike protein peptide pool stimulation. B) Magnitude of SARS-CoV-2 Spike-specific $\mathrm{CD}^{+} \mathrm{T}$ cell responsiveness in select study participants split by duration of self-reported duration of COVID-19 symptoms. Plotted values are background subtracted from a total of 10 subjects. C) Correlation analysis of SARS-CoV-2 specific cellular immunity as defined by CD8+ flow cytometry and IFN-g ELISPOT. $r^{2}$ and $p$ value calculated by 2 -tailed Pearson Correlation test. D) Representative flow cytometry plot demonstrating CD134 and CD69 upregulation in CD4+ T cells following SARSCoV-2 Spike protein peptide pool stimulation. E) Magnitude of SARS-CoV-2 Spike-specific CD4+ T cell immunity in select study participants split by duration of self-reported duration of COVID-19 symptoms. Plotted values are background subtracted from a total of 10 subjects. F) Correlation analysis of SARS-CoV-2 specific cellular immunity as defined by CD4+ flow cytometry and IFN-g ELISPOT. $r^{2}$ and $\mathrm{p}$ value calculated by 2 -tailed Pearson Correlation test.

Figure 4. Transcriptional analysis of SARS-CoV-2 reactive $\mathrm{CD4}^{+} \mathbf{T}$ cells A) Heatmap display of normalized gene expression in sorted SARS-CoV-2 reactive CD4 T cells from total of 10 convalescent COVID-19 patients. Patients are separated by duration of self-reported COVID-19 symptoms. B) PCA analysis of total normalized gene expression data from sorted SARS-CoV-2 reactive CD4 T cells from total of 10 convalescent COVID-19 patients. Patients separated by duration of self-reported COVID-19 symptoms.

Figure 5. Assessment of seasonal human coronavirus cellular immunity in convalescent COVID-19 donors. A) Magnitude of 229E Spike protein specific cellular immunity in all study participants split by duration of self-report COVID-19 symptoms. B) Magnitude of NL63 Spike protein specific cellular immunity in all study participants split by duration of self-report COVID-19 symptoms. C) Correlation table assessing the relationship between NL63, 229E, and SARS-CoV-2 Spike protein reactivity in all 
medRxiv preprint doi: https://doi.org/10.1101/2021.01.29.21250771; this version posted February 1,2021 . The copyright holder for this preprint (which was not certified by peer review) is the author/funder, who has granted medRxiv a license to display the preprint in perpetuity.

It is made available under a CC-BY-NC-ND 4.0 International license .

463 subjects and the magnitude of reactivity against other human coronavirus antigens included in the study. $464 \quad r^{2}$ and $p$ value calculated by 2-tailed Pearson Correlation test. D) Relationship between subject age and 465 total 229E/NL63 Spike protein specific cellular immune response. Filled circles indicate subjects

466 included in the "short" duration of symptoms group. Empty circles indicate individuals included in the 467 468 
medRxiv preprint doi: https://doi.org/10.1101/2021.01.29.21250771; this version posted February 1, 2021. The copyright holder for this preprint (which was not certified by peer review) is the author/funder, who has granted medRxiv a license to display the preprint in perpetuity. It is made available under a CC-BY-NC-ND 4.0 International license .

\section{REFERENCES}

1. Lu, R., et al., Genomic characterisation and epidemiology of 2019 novel coronavirus: implications for virus origins and receptor binding. Lancet, 2020. 395(10224): p. 565-574.

2. Zhu, N., et al., A Novel Coronavirus from Patients with Pneumonia in China, 2019. N Engl J Med, 2020. 382(8): p. 727-733.

3. Zhou, P., et al., A pneumonia outbreak associated with a new coronavirus of probable bat origin. Nature, 2020. 579(7798): p. 270-273.

4. Guan, W.J., et al., Clinical Characteristics of Coronavirus Disease 2019 in China. N Engl J Med, 2020. 382(18): p. 1708-1720.

5. Huang, C., et al., Clinical features of patients infected with 2019 novel coronavirus in Wuhan, China. Lancet, 2020. 395(10223): p. 497-506.

6. Chen, N., et al., Epidemiological and clinical characteristics of 99 cases of 2019 novel coronavirus pneumonia in Wuhan, China: a descriptive study. Lancet, 2020. 395(10223): p. 507513.

7. Dan, J.M., et al., Immunological memory to SARS-CoV-2 assessed for up to 8 months after infection. Science, 2021.

8. $\quad$ Rodda, L.B., et al., Functional SARS-CoV-2-Specific Immune Memory Persists after Mild COVID-19. Cell, 2021. 184(1): p. 169-183 e17.

9. Carfi, A., et al., Persistent Symptoms in Patients After Acute COVID-19. JAMA, 2020. 324(6): p. 603-605.

10. Del Rio, C., L.F. Collins, and P. Malani, Long-term Health Consequences of COVID-19. JAMA, 2020.

11. Tenforde, M.W., et al., Symptom Duration and Risk Factors for Delayed Return to Usual Health Among Outpatients with COVID-19 in a Multistate Health Care Systems Network - United States, March-June 2020. MMWR Morb Mortal Wkly Rep, 2020. 69(30): p. 993-998.

12. Li, N., X. Wang, and T. Lv, Prolonged SARS-CoV-2 RNA shedding: Not a rare phenomenon. J Med Virol, 2020. 92(11): p. 2286-2287.

13. Park, S.K., et al., Detection of SARS-CoV-2 in Fecal Samples From Patients With Asymptomatic and Mild COVID-19 in Korea. Clin Gastroenterol Hepatol, 2020.

14. Wolfel, R., et al., Virological assessment of hospitalized patients with COVID-2019. Nature, 2020. 581(7809): p. 465-469.

15. Gaebler, C., et al., Evolution of antibody immunity to SARS-CoV-2. Nature, 2021.

16. $\mathrm{Ng}, \mathrm{C} . \mathrm{T}$., et al., Networking at the level of host immunity: immune cell interactions during persistent viral infections. Cell Host Microbe, 2013. 13(6): p. 652-64.

17. Yi, J.S., M.A. Cox, and A.J. Zajac, T-cell exhaustion: characteristics, causes and conversion. Immunology, 2010. 129(4): p. 474-81.

18. Wherry, E.J., T cell exhaustion. Nat Immunol, 2011. 12(6): p. 492-9.

19. Sette, A. and S. Crotty, Pre-existing immunity to SARS-CoV-2: the knowns and unknowns. Nat Rev Immunol, 2020. 20(8): p. 457-458.

20. Grifoni, A., et al., Targets of T Cell Responses to SARS-CoV-2 Coronavirus in Humans with COVID-19 Disease and Unexposed Individuals. Cell, 2020. 181(7): p. 1489-1501 e15.

21. Le Bert, N., et al., SARS-CoV-2-specific T cell immunity in cases of COVID-19 and SARS, and uninfected controls. Nature, 2020. 584(7821): p. 457-462.

22. Gallais, F., et al., Intrafamilial Exposure to SARS-CoV-2 Associated with Cellular Immune Response without Seroconversion, France. Emerg Infect Dis, 2021. 27(1). 
medRxiv preprint doi: https://doi.org/10.1101/2021.01.29.21250771; this version posted February 1, 2021. The copyright holder for this preprint (which was not certified by peer review) is the author/funder, who has granted medRxiv a license to display the preprint in perpetuity.

It is made available under a CC-BY-NC-ND 4.0 International license .

23. Sekine, T., et al., Robust T Cell Immunity in Convalescent Individuals with Asymptomatic or Mild COVID-19. Cell, 2020. 183(1): p. 158-168 e14.

24. Weiskopf, D., et al., Phenotype and kinetics of SARS-CoV-2-specific T cells in COVID-19 patients with acute respiratory distress syndrome. Sci Immunol, 2020. 5(48).

25. Diao, B., et al., Reduction and Functional Exhaustion of T Cells in Patients With Coronavirus Disease 2019 (COVID-19). Front Immunol, 2020. 11: p. 827.

26. Kusnadi, A., et al., Severely ill COVID-19 patients display impaired exhaustion features in SARS-CoV-2-reactive CD8(+) T cells. Sci Immunol, 2021. 6(55).

27. Newell, K.L., et al., Switched and unswitched memory B cells detected during SARS-CoV-2 convalescence correlate with limited symptom duration. medRxiv, 2020.

28. Bray, N.L., et al., Erratum: Near-optimal probabilistic RNA-seq quantification. Nat Biotechnol, 2016. 34(8): p. 888.

29. Soneson, C., M.I. Love, and M.D. Robinson, Differential analyses for RNA-seq: transcript-level estimates improve gene-level inferences. F1000Res, 2015. 4: p. 1521.

30. Robinson, M.D., D.J. McCarthy, and G.K. Smyth, edgeR: a Bioconductor package for differential expression analysis of digital gene expression data. Bioinformatics, 2010. 26(1): p. $139-40$.

31. McCarthy, D.J., Y. Chen, and G.K. Smyth, Differential expression analysis of multifactor RNASeq experiments with respect to biological variation. Nucleic Acids Res, 2012. 40(10): p. 428897.

32. Ritchie, M.E., et al., limma powers differential expression analyses for RNA-sequencing and microarray studies. Nucleic Acids Res, 2015. 43(7): p. e47. 
Table 1. Convalescent COVID-19 patient characterization

602

Table 2. Patterns of SARS-CoV-2 reactivity in convalescent COVID-19 patients

\begin{tabular}{|l|l|l|l|}
\hline & All subject $(\mathbf{n}=\mathbf{8 4})$ & $\begin{array}{c}\text { Short duration of } \\
\text { symptoms }(\mathbf{n}-14)\end{array}$ & $\begin{array}{c}\text { Long duration of } \\
\text { symptoms }(\mathbf{n}-\mathbf{1 9})\end{array}$ \\
\hline Age (mean) & $49(20-85)$ & $49(22-65)$ & $52(23-72)$ \\
\hline $\begin{array}{l}\text { Duration of } \\
\text { symptoms (mean) }\end{array}$ & 14 days $(0-61)$ & 4.6 days $(0-8)$ & 26.7 days $(18-61)$ \\
\hline Sex (M/F) & $33 / 51$ & $7 / 7$ & $3 / 16$ \\
\hline
\end{tabular}

608

\begin{tabular}{|l|l|l|l|}
\hline Virus & Antigen & $\begin{array}{l}\text { Short duration of } \\
\text { symptoms }(<\mathbf{8} \text { days })\end{array}$ & $\begin{array}{l}\text { Long duration of } \\
\text { symptoms (>18 days) }\end{array}$ \\
\hline SARS-CoV-2 & Any & $85.7 \%(12 / 14)$ & $94.7 \%(18 / 19)$ \\
\hline SARS-CoV-2 & Spike & $71.4 \%(10 / 14)$ & $89.5 \%(17 / 19)$ \\
\hline SARS-CoV-2 & $\mathrm{N}$ & $85.7 \%(12 / 14)$ & $57.9 \%(11 / 19)$ \\
\hline SARS-CoV-2 & $\mathrm{M}$ & $50 \%(7 / 14)$ & $68.4 \%(13 / 19$ \\
\hline SARS-CoV-2 & ORF3a & $7.1 \%(1 / 14)$ & $26.3 \%(5 / 19)$ \\
\hline SARS-CoV-2 & ORF7a & $0 \%(0 / 14)$ & $5.2 \%(1 / 19)$ \\
\hline 229E & Spike & $50 \%(7 / 14)$ & $26.3 \%(5 / 19)$ \\
\hline NL63 & Spike & $50 \%(7 / 14)$ & $36.8 \%(7 / 19)$ \\
\hline
\end{tabular}


Figure 1

A)

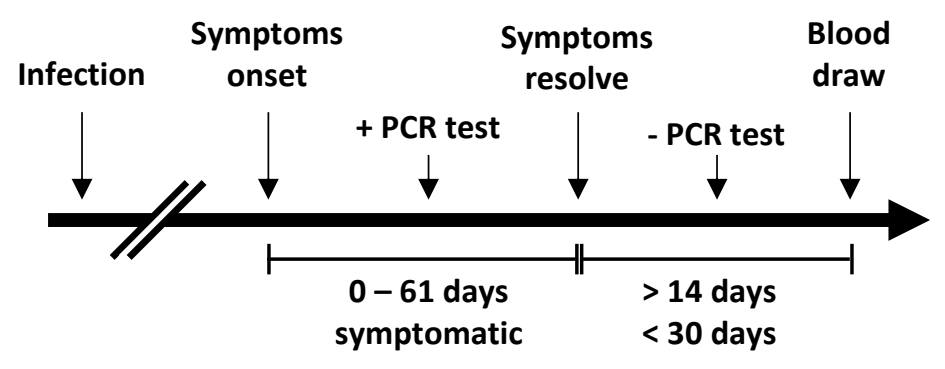

B)

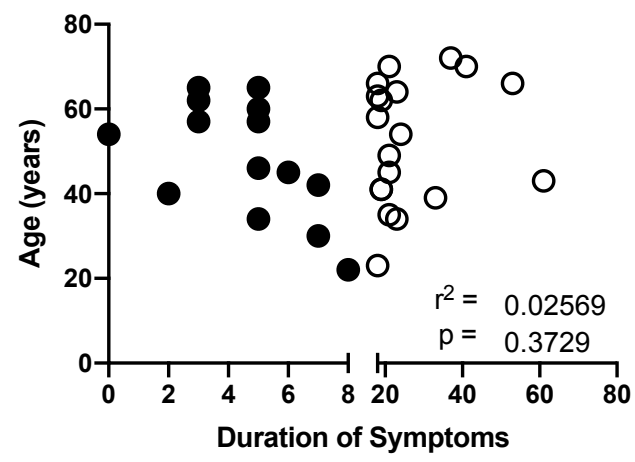


Figure 3.

A)

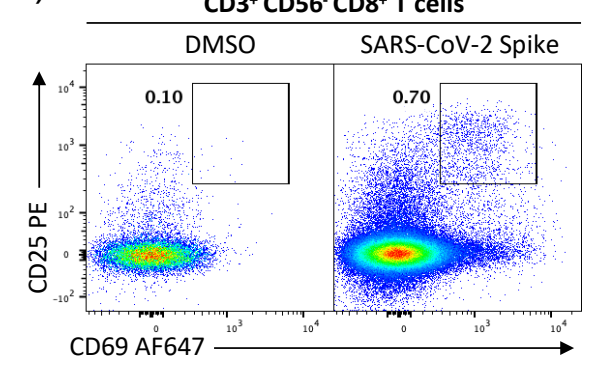

D)

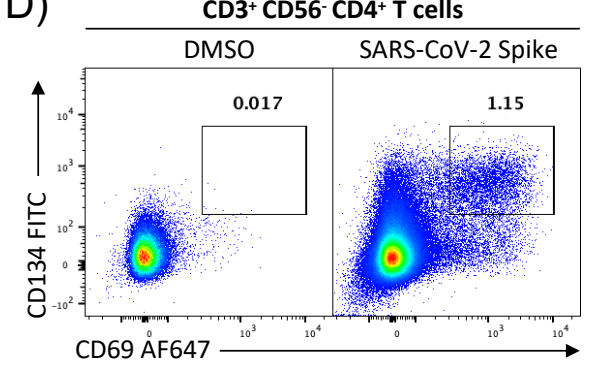

B)

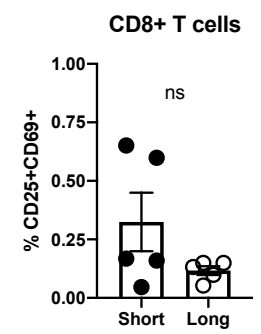

E)

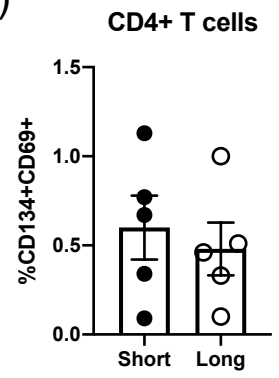

C)

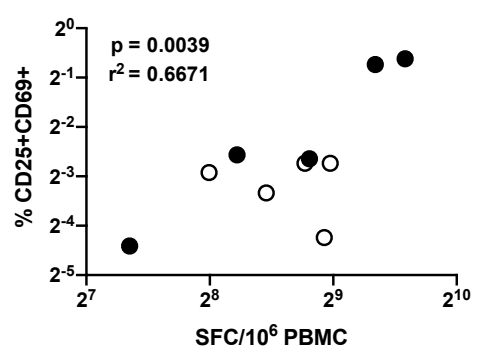

F)

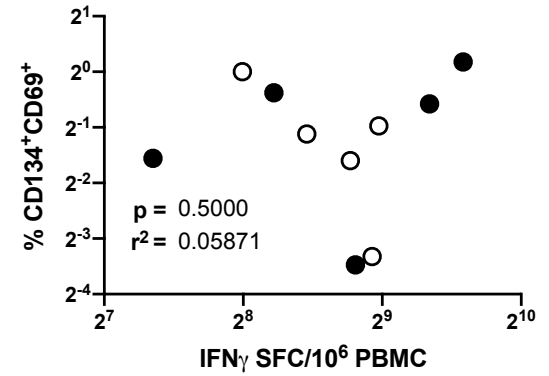




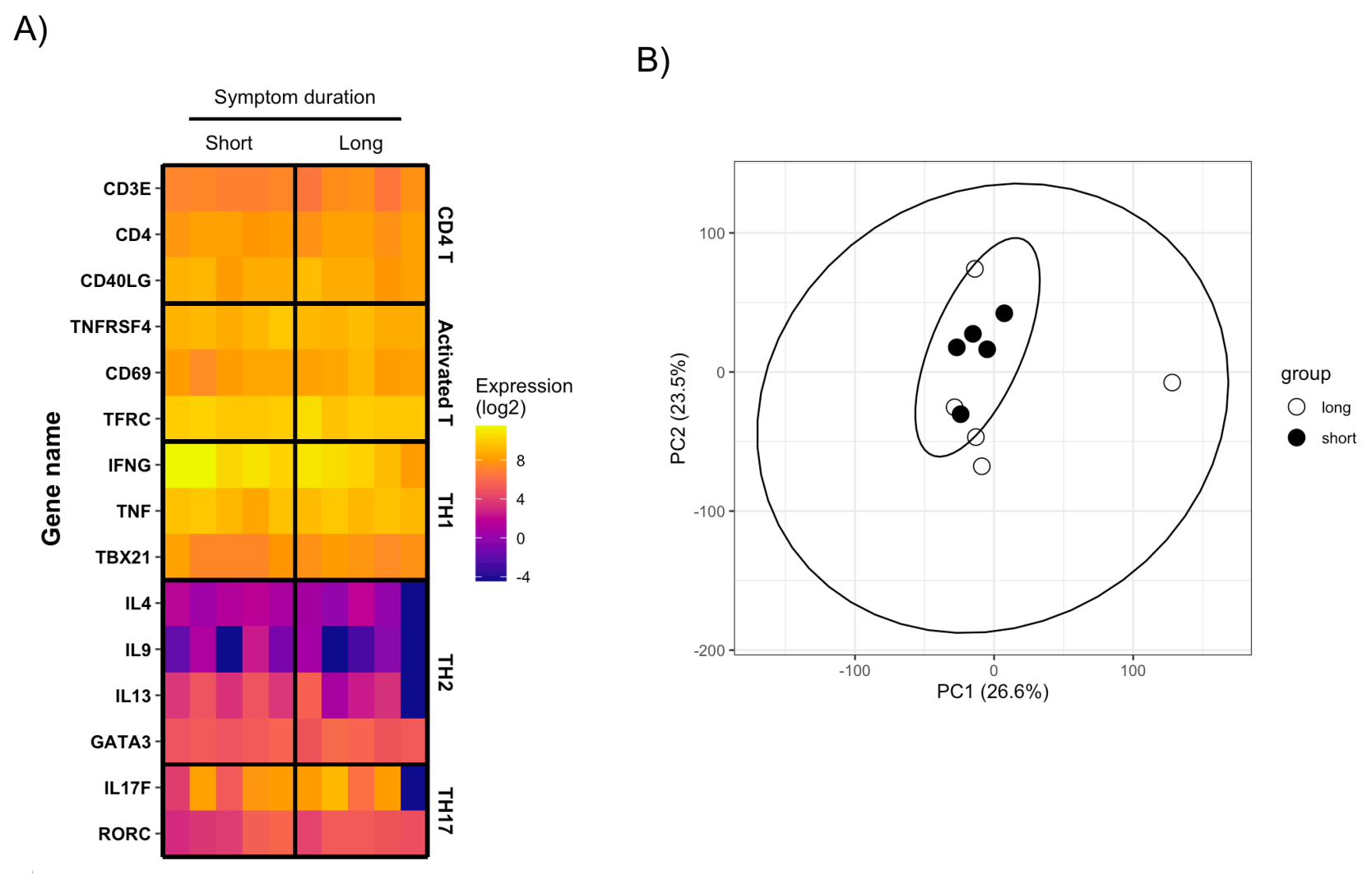

Figure 4.

A
B) 


\section{Figure 5}

A)

229E Spike

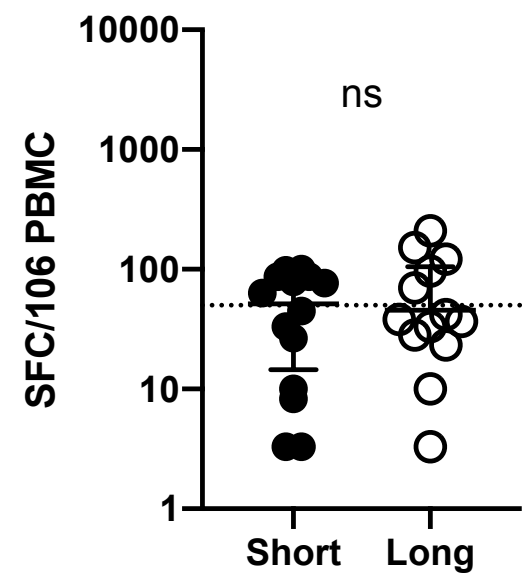

B) NL63 Spike

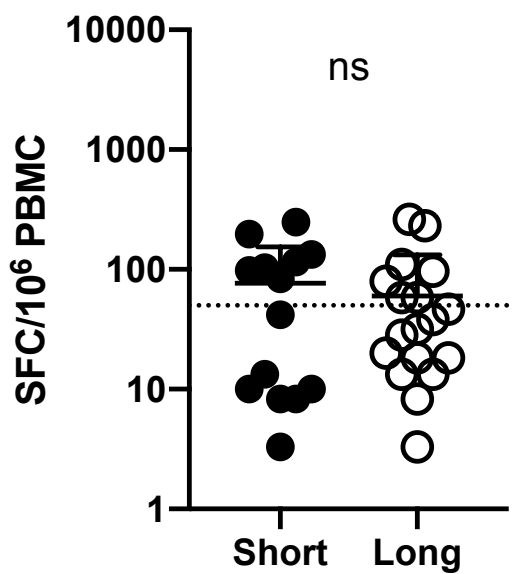

C)

Spike protein

\begin{tabular}{|c|c|c|c|c|c|c|c|}
\hline \multirow{3}{*}{ NL63 } & NL63 & $229 \mathrm{E}$ & SARS-CoV-2 & $\mathbf{N}$ & $\mathbf{M}$ & ORF3a & ORF7a \\
\hline & -- & $r^{2}=0.3658$ & $r^{2}=0.00199$ & $r^{2}=0.2423$ & $r^{2}=0.001411$ & $r^{2}=0.01078$ & $r^{2}=0.04595$ \\
\hline & -- & $p=0.0002$ & $p=0.8053$ & $p=0.0036$ & $p=0.8356$ & $p=0.5653$ & $p=0.231$ \\
\hline & $p=0.0002$ & -- & $p=0.8884$ & $p=0.0024$ & $p=0.6923$ & $p=0.7776$ & $p=0.2148$ \\
\hline & $r^{2}=0.00199$ & $r^{2}=0.000646$ & -- & $r^{2}=0.3028$ & $r^{2}=0.5401$ & $r^{2}=0.2664$ & $r^{2}=0.000714$ \\
\hline
\end{tabular}

D)

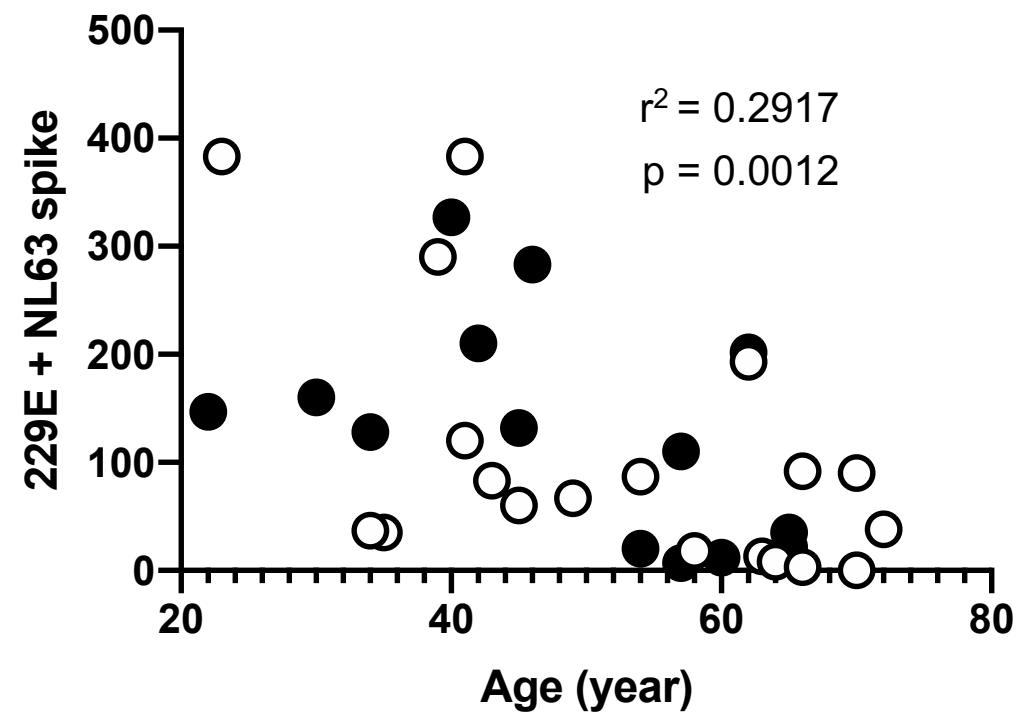




\section{Supplemental figure 1.}

\section{Subject \#1}

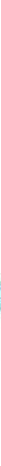

Subject \#2

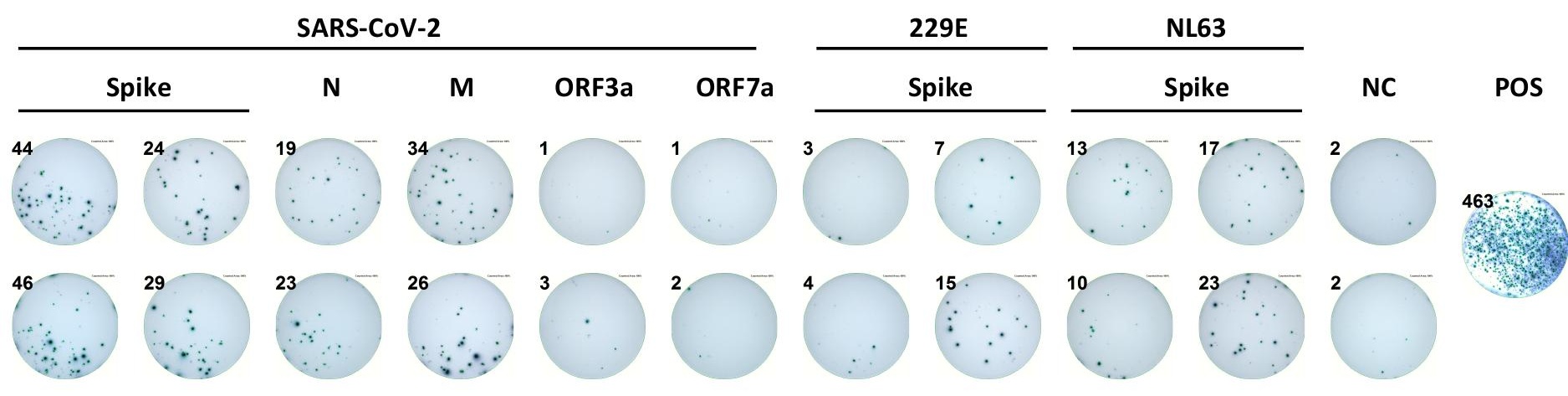

Supplemental Figure 1. Representative IFN- $\gamma$ ELISPOT plate images 


\section{Supplemental figure 2 .}
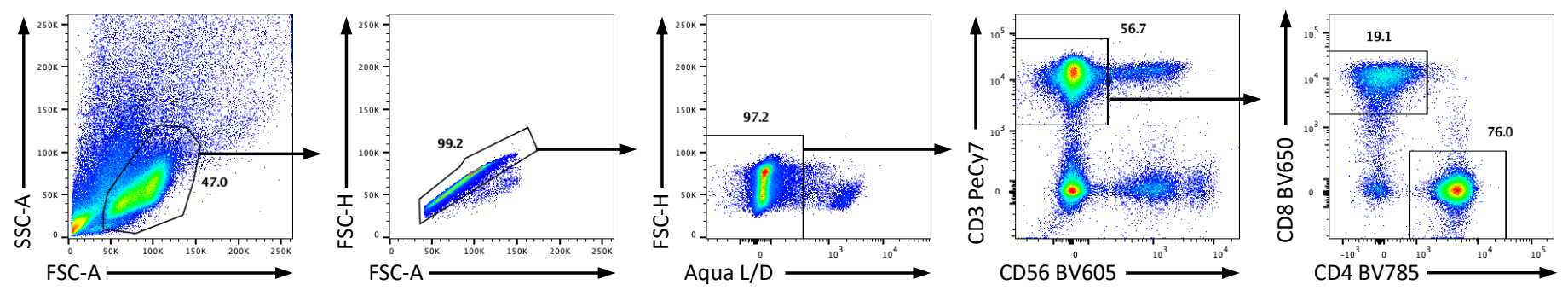

Supplemental Figure 2. Gating scheme for activated CD4 and CD8 T cell isolation 
Supplemental figure 3.

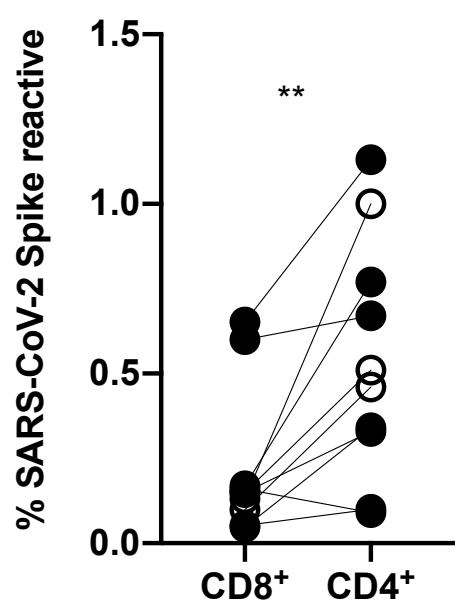

Supplemental Figure 3. Background-subtracted frequency of SARS-CoV-2 Spike reactive CD8+ and CD4+ T cells in 10 select convalescent COVID-19 patients. ${ }^{* *} p<0.01$ two-tailed paired T test. 


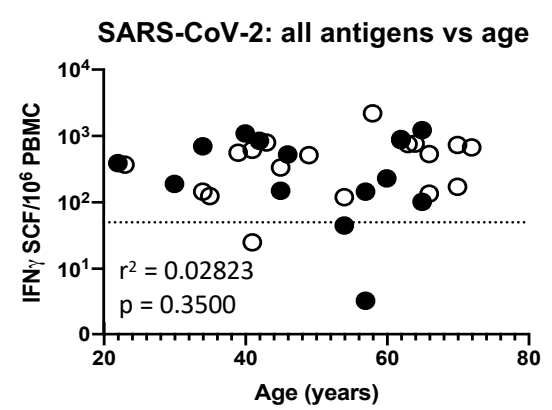

SARS-CoV-2: Spike vs age
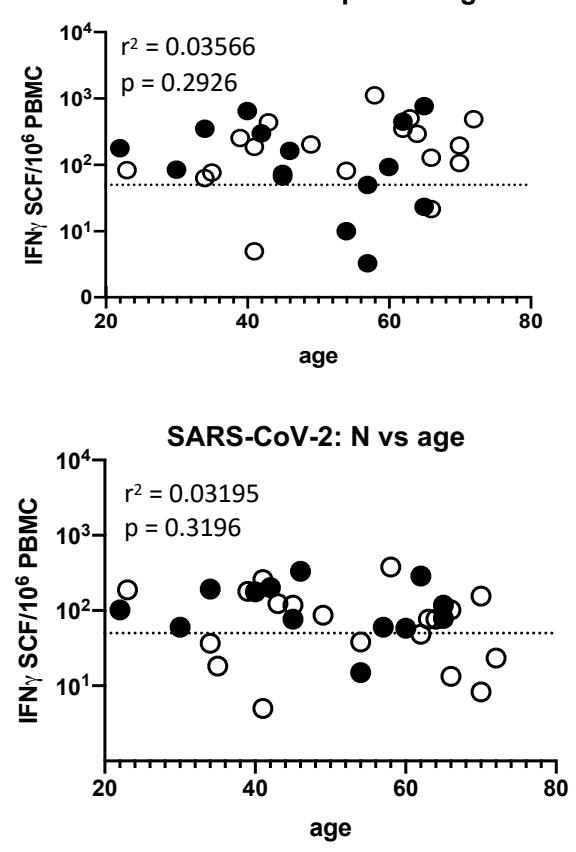
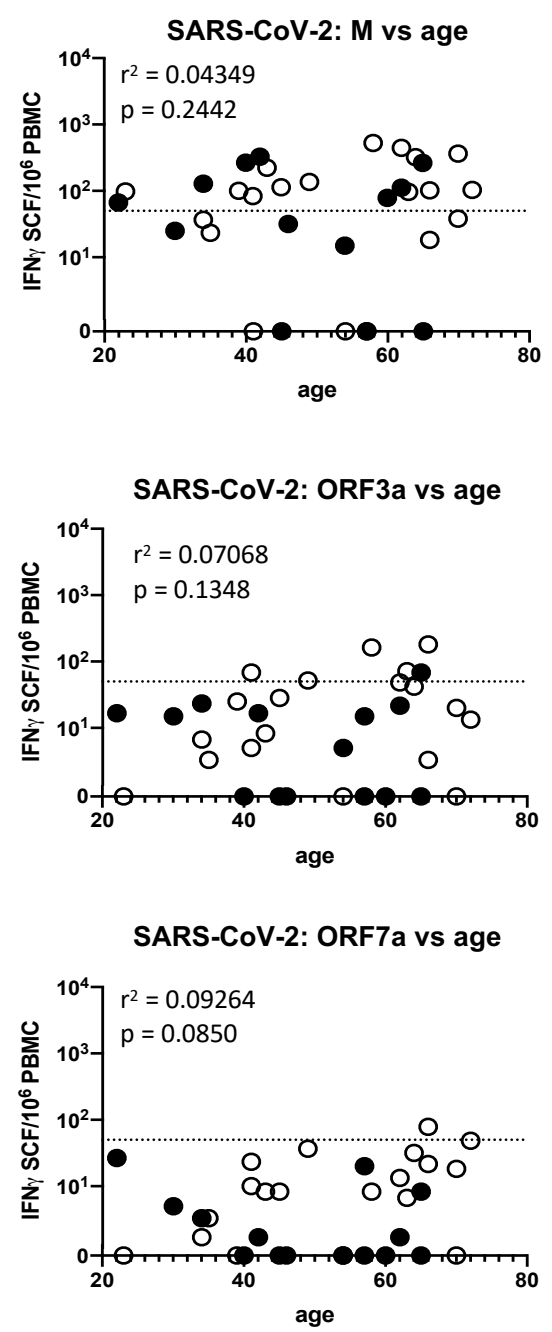

Supplemental Figure 4. Relationship between age and SARS-CoV-2 antigen reactivity as assessed by IFN-g ELISPOT. Pearson correlation calculations were used to determine $r 2$ and two-tailed $p$ values. Dashed line indicates the $50 \mathrm{IFN}-\gamma \mathrm{SFC} / 10^{6} \mathrm{PBMC}$ threshold for positivity 